\title{
Effect of Gamma Irradiation on Carotenoids and Vitamin C Contents of Papaya Fruit (Carica papaya L.) Cv. Golden
}

Suely Gomes de Figueiredo ${ }^{1 *}$, Geralda Gillian Silva-Sena', Enilton Nascimento de Santana ${ }^{2}$, Raquel Gouvêa dos Santos ${ }^{3}$, João Oiano Neto ${ }^{4}$ and Cristiane Alves de Oliveira ${ }^{5}$

${ }^{1}$ Laboratório de Química de Proteínas, Universidade Federal do Espírito Santo, 29040-091, Vitória, ES, Brazil

${ }^{2}$ Assistência Técnica e Extensão Rural, Instituto Capixaba de Pesquisa, (Incaper), 29900-970, Linhares, ES, Brazil

${ }^{3}$ Laboratório de Radiobiologia, Centro de Desenvolvimento da Tecnologia Nuclear (CDTN/CNEN), 30161-970, Belo Horizonte, MG, Brazil

${ }^{4}$ Embrapa Agroindústria de Alimentos, 23020-470, Rio de Janeiro, RJ, Brazil

${ }^{5}$ Universidade Federal de Viçosa, Viçosa, MG, Brazil

\begin{abstract}
The irradiation has been considered an alternative process for decay control extending shelf life of fresh fruits. This study was conducted to investigate the effect of gamma irradiation on functional constituents on papaya fruits cv. Golden. Fruits were harvested into maturation 1 degree (stage) and irradiated with $0.8 \mathrm{kGy}$ (Cobalt 60 source-MSD Nordion irradiator), and then stored at $24 \pm 2^{\circ} \mathrm{C}$. Total carotenoids and vitamin $\mathrm{C}$ contents were evaluated in the pulp fruits, in the $5,7 \mathrm{e} 9^{\text {th }}$ days post-harvest by a reversed-phase and ion exclusion column by a high performance liquid chromatography. Results demonstrated that the irradiation induced alterations in the total carotenoids and vitamin $\mathrm{C}$ levels. However, these changes did not affect the adequacy of vitamins $A$ and $C$ (for adult and children) in relation to daily nutritional requirements. In conclusion, the present data provide evidence that the irradiated papaya, did not impair reduce these nutritional characteristics.
\end{abstract}

Keywords: Papaya; Carotenoids; Vitamin C; Irradiation

\section{Introduction}

Gamma irradiation in food technology has been considered an effective process for decay control, extending shelf life of a wide variety of highly perishable fruits due to the fast ripening after harvest). Studies have shown that irradiation increases the shelf life of various tropical and subtropical fruits such as papayas, mangoes and bananas [1-3] and also leads to the inactivation of microorganisms [4]. However, irradiation process can produce serious undesirable effects on food nutritional quality [5].

Papaya fruits are highly appreciated by consumers due to their sensorial and nutritional characteristics, being an important constituent of the human diet either directly or as papaya-based food products.

Epidemiological studies indicated that carotenoids and vitamin C, abundant bioactive compounds in papaya fruits, are among the diet constituents postulated to play a preventive role in cancer, cardiovascular illness and anti-aging [6], based on their antioxidant capacity. Therefore, recommendations have been made in order to increase the daily intake of fruits rich in these nutrients, like papaya.

Some carotenoids, such as $\alpha$-carotene, $\beta$-carotene and $\beta$-cryptoxanthin, present provitamin A activity that is transformed into retinal by mammals, which avoids the risk of blindness in million preschool children [6,7]. Although lycopene is not a vitamin A precursor, it presents an antioxidant activity and is also involved in cell communication, hormone modulation and immune system [8].

It is well known that carotenoids and vitamins $\mathrm{C}$ and $\mathrm{A}$ are extremely susceptible to degradation due to their unsaturated structure. These substances are sensitive to heat, oxygen and light [9].

Although a significant amount of research has been conducted on the irradiation of fruits, very little information is available about the effect of irradiation on carotenoids and vitamin $\mathrm{C}$, in papaya fruits. Considering this issue and the carotenoids and vitamin $\mathrm{C}$ instability, the present study was undertaken to evaluate the gamma radiation effect on papaya fruits cv. Golden contents of carotenoids and vitamin C. In addition, the adequacy of the vitamin A value and vitamin $\mathrm{C}$ irradiated fruits to the Dietary Reference Intakes was evaluated.

\section{Materials and Methods}

\section{Fruit material and Irradiation}

Papaya fruits cv. "Golden" were harvested in Linhares-ES, Brazil, into maturation 1 degree (according to classification of Marin et al. [10]) and were washed with chlorinated water (1,5 ppm) in a packing line of Caliman Agricola S/A (Linhares, Espírito Santo, Brazil). After fruits selection (considering absence of physical defects, signs of pathogenic contamination and differences in size and color), they were separated in two groups: control (C) and irradiated (I) groups. Fruits in I group were exposed to irradiation of $0.8 \mathrm{kGy}$ (Cobalt 60 sourceMSD Nordion irradiator) on the first day post-harvest ( $\left.1^{\text {st }} \mathrm{dph}\right)$. Fruits in I and $\mathrm{C}$ groups were maintained at $24 \pm 2{ }^{\circ} \mathrm{C}$, and pulp samples were taken on the $5^{\text {th }}, 7^{\text {th }}$ and $9^{\text {th }}$ days post-harvest and stored at $-80^{\circ} \mathrm{C}$ until required. Three replicates were performed for all ripening stages of each group and the analyses were done in duplicate, randomicaly.

\section{Extraction of carotenoids and vitamin C}

For carotenoids extraction, the fruit pulp was ground with the help of acetone and filtered using a sintered wafer funnel. This procedure was repeated until the residue became colorless and pigments fractions were transferred to petroleum ether and then washed with distilled

*Corresponding author: Suely Gomes de Figueiredo, Laboratório de Química de Proteínas, Universidade Federal do Espírito Santo, 29040-091, Vitória, ES, Brazil, Tel: 55278181 184; E-mail: suelygf@gmail.com

Received March 13, 2014; Accepted June 12, 2014; Published June 20, 2014

Citation: de Figueiredo SG, Silva-Sena GG, de Santana EN, dos Santos RG Neto JO, et al. (2014) Effect of Gamma Irradiation on Carotenoids and Vitamin C Contents of Papaya Fruit (Carica papaya L.) Cv. Golden. J Food Process Technol 5: 337. doi:10.4172/2157-7110.1000337

Copyright: ( 2014 Figueiredo SG, et al. This is an open-access article distributed under the terms of the Creative Commons Attribution License, which permits unrestricted use, distribution, and reproduction in any medium, provided the original author and source are credited. 


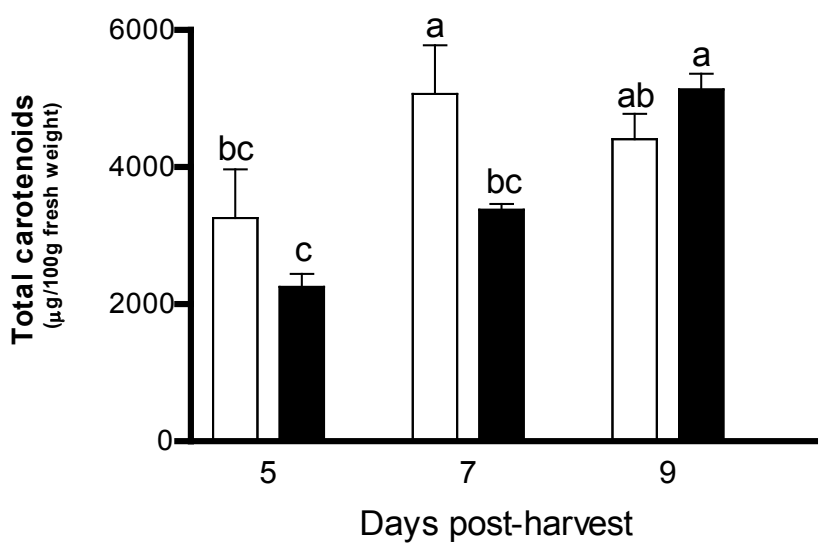

$\square$ Control Irradiated

Figure 1: Comparison of total carotenoids in the pulp of control and irradiated groups of papaya fruits on the $5^{\text {th }}, 7^{\text {th }}$ and $9^{\text {th }}$ days post-harvest based on fresh weight. Means followed by same letter were not significantly different at $p<0.05$ (Tukey test).

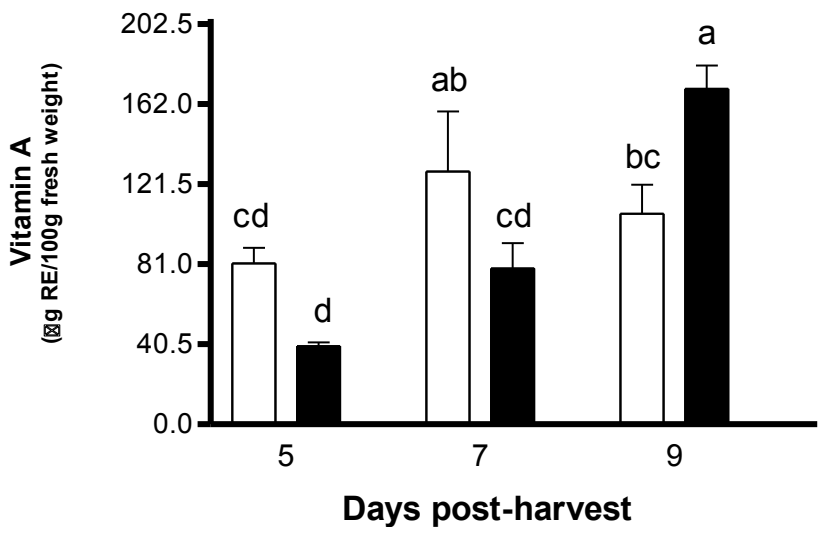

Figure 2: Comparison of vitamin A value for the content of $\beta$-cryptoxanthin and $\beta$-carotene in the pulp of control and irradiated groups of papaya fruits on the $5^{\text {th }}$ $7^{\text {th }}$ and $9^{\text {th }}$ days post-harvest based on fresh weight. Means followed by same letter were not significantly different at $p<0.05$ (Tukey test).

water for complete acetone removal, according to Rodriguez-Amaya [11].

Fruit pulp was homogenized in a tissue homogenizer, shaked in sonicator with suprapur sulfuric acid and filtered using a hydrophilic Teflon filter for extraction of vitamin C, according to Rosa et al. [12].

\section{Chromatographic analyses}

The quantification was carried out by High Performance Liquid Chromatography (HPLC) using Waters model 2695 Alliance system equipped with a model 2996 photo diode array detector UV/Vis based on the procedure described by Rodriguez-Amaya [11] and Rosa et al. [12]. The following apparatus were used: (a) Carotenoids - Ten microliters of the carotenoids extract were injected into the reverse phase column YMC30 Carotenoid S-3 $(4.6 \mathrm{~mm} \times 250 \mathrm{~mm})$. The mobile phase contained methanol: terc-butyl methyl ether $80: 20 \mathrm{v} / \mathrm{v}$; and the carotenoids were eluted with the isocratic gradient; flow rate of $0.8 \mathrm{~mL} \mathrm{~min}{ }^{-1}$ and run time: $28 \mathrm{~min}$; temperatures of the column and the injector: $30^{\circ} \mathrm{C}$ and room temperature, respectively; (b) Vitamin $\mathrm{C}$ - twenty microliters of the vitamin $\mathrm{C}$ extract were injected into the reverse phase/ion exchange column Aminex HPX-87H (7.8 mm $\times 300$ $\mathrm{mm}$ ). The vitamin $\mathrm{C}$ was eluted by isocratic gradient using suprapur sulfuric acid $0.1 \mathrm{~N}$ as mobile phase; flow rate of $0.8 \mathrm{~mL} \mathrm{~min}^{-1}$ and run time: $12 \mathrm{~min}$; temperatures of the column and the injector: room temperature e $10^{\circ} \mathrm{C}$, respectively.

The carotenoids and vitamin $\mathrm{C}$ were detected by absorbance at 450 $\mathrm{nm}$ and $243 \mathrm{~nm}$, respectively. The concentration of carotenoids and vitamin $\mathrm{C}$ in the samples were determined by the automatic integration of the areas of the peaks and compared to their respective standard curves.

The ascorbic acid standard was purchased from Sigma and for carotenoids; analytical standards ( $\beta$-carotene, lycopene and $\beta$-cryptoxanthin) were obtained from natural sources kindly provided by Embrapa Agroindústria de Alimentos - Rio de Janeiro/Brazil.

Results were expressed as $\mu \mathrm{g}$ (for carotenoids) or mg (for vitamin C) per $100 \mathrm{~g}$ of fresh weight.

\section{Determination of Vitamin A}

Vitamin A value was determined based on the vitamin A activity of its carotenoids precursors ( $\beta$-carotene and $\beta$-cryptoxanthin), according to Bauernfeind [13], using conversion factors provided by the National Academy of Sciences - National Council Research [14]. Vitamin A value was expressed in RE (retinol equivalents) per $100 \mathrm{~g}$ of fresh weight. It is know that $6 \mu \mathrm{g}$ of $\beta$-carotene e $12 \mu \mathrm{g}$ de $\beta$-cryptoxanthin are equivalent to $1 \mu \mathrm{g}$ of retinol (RE) [14].

\section{Vitamins adequacy}

Adequacy of vitamin A and vitamin $\mathrm{C}$ for adult and children was evaluated according to DRI's - Dietary Reference Intakes [15].

\section{Statistical analysis}

The data was analyzed using the analysis of variance (ANOVA) and the differences between the samples means were determined by Tukey's test with a significance level of $\mathrm{p}<0.05$. The statistical analysis of the data was performed using "SAEG" (System for Statistical Analysis) version 4.10-92.

\section{Results}

\section{Total carotenoids}

Changes in total carotenoids profile due to gamma irradiation of papaya fruits were evaluated. The results obtained from the analysis of total carotenoids in the pulp of control (C) and irradiated (I) groups of papaya fruits are shown in Figure 1. There was no significant difference in the carotenoids content between $\mathrm{C}$ and I groups on the $5^{\text {th }}$ and $9^{\text {th }}$ dph. However, it was observed that the irradiated fruit showed lower levels of total carotenoids (a decrease of 35\%) on the $7^{\text {th }} \mathrm{dph}$.

The vitaminical potential in irradiated fruits was low on the $7^{\text {th }} \mathrm{dph}$ (78.8 $\mu \mathrm{g} \mathrm{RE} / 100 \mathrm{~g} \pm 12.9)$ and high on the $9^{\text {th }} \mathrm{dph}(\mathrm{I}-169.7 \mu \mathrm{g} \mathrm{RE} / 100 \mathrm{~g}$ \pm 11.9 ) when compared to control fruits (C-127,9 $\mu \mathrm{g} \mathrm{RE} / 100 \mathrm{~g} \pm 30,4$ and $106.5 \mu \mathrm{g} R E / 100 \mathrm{~g} \pm 14.76$ respectively).

Interestingly, the vitamin A activity in irradiated fruits on the $9^{\text {th }}$ dph $(169.7 \mu \mathrm{g} R / 100 \mathrm{~g} \pm 11.9)$ was statistically similar to that in the control group $(127.9 \mu \mathrm{g} \mathrm{RE} / 100 \mathrm{~g} \pm 30.4)$ on the $7^{\text {th }} \mathrm{dph}$. Figure 2 shows the results obtained from the analysis of vitamin A value (calculated using the levels of $\beta$-carotene and $\beta$-cryptoxanthin). 


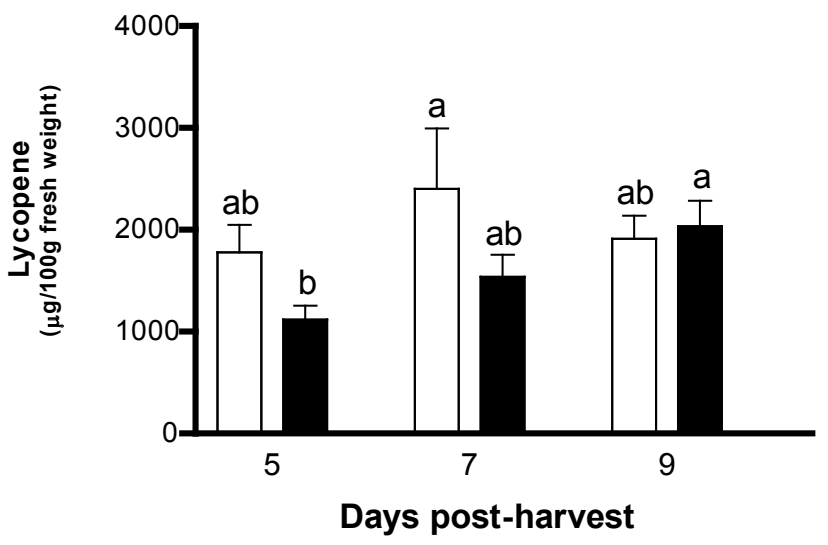

Figure 3: Comparison of lycopene content in the pulp of control and irradiated groups of papaya fruits on the $5^{\text {th }}, 7^{\text {th }}$ and $9^{\text {th }}$ days post-harvest based on fresh weight. Means followed by same letter were not significantly different at $p<0.05$ (Tukey test).

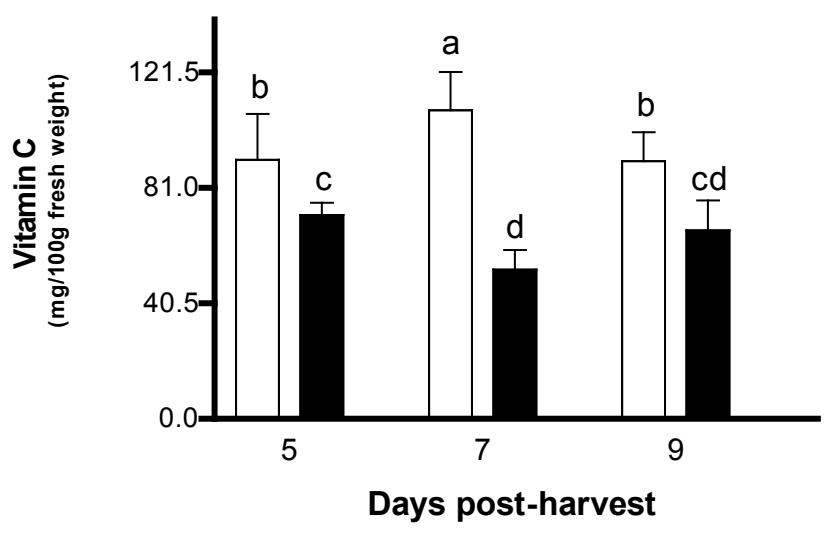

$\square$ Control

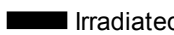

Figure 4: Comparison of the vitamin $C$ content in the pulp of control and irradiated groups of papaya fruits on the $5^{\text {th }}, 7^{\text {th }}$ and $9^{\text {th }}$ days post-harvest based on fresh weight. Means followed by same letter were not significantly different at $\mathrm{p}<0.05$ (Tukey test).

Unlike the results for total carotenoids and vitamin A value, it was not found a significant difference in levels of lycopene between $\mathrm{C}$ and I groups as measured on the evaluated days post-harvest (Figure 3).

As shown in Figure 4, the vitamin C content of irradiated fruits was markedly lower than the content observed in the control group on the evaluated days post-harvest $\left(\approx 21 \%-5^{\text {th }} \mathrm{dph} ; 52 \%-7^{\text {th }} \mathrm{dph}\right.$ and $27 \%-9^{\text {th }}$ $\mathrm{dph})$.

\section{Discussion}

There are numerous evidences supporting the hypothesis that fruits contain health- promoting compounds, a crucial parameter of the acceptance by consumers. Fruits as papayas are very appreciated by consumers mainly due to their nutritional quality and importance as a source of Vitamin $\mathrm{C}$ and carotenoids in human diet.

However, little information is available about changes in the content of these compounds during ripening process and application of postharvest conservation processes.

The irradiation provides an effective alternative process to maintain the shelf life of perishable fruits. Our previous study showed that gamma radiation caused a delay in the papaya ripening, retaining the firmness for 4 days. In the present study, we evaluated the effect of 0.8 kGy irradiation on papaya carotenoids and vitamin C contents. High levels of these compounds, their antioxidant capacity and related health benefits, are considered an adjunctive quality parameter of papaya.

It was established to test a $0.8 \mathrm{KGy}$ dose of gamma radiation, taking into account previous experimental observation in our laboratory which demonstrated that 0.6 and $1.0 \mathrm{kGy}$ doses in a group of 'solo' Golden papayas were effective in the maintenance of pulp firmness. However, $1.0 \mathrm{kGy}$ caused damage in the visual quality, due to darkening of the skin and irregular fruit ripening which negatively influences the consumer market acceptability. The fruit chemical analysis were carried out on the $5^{\text {th }}, 7^{\text {th }}$ and $9^{\text {th }} \mathrm{dph}$, considering the pulp texture able for consumption and internal and external visual aspect of the fruits (data not shown).

\section{Carotenoids}

Total carotenoids content of the papaya fruits was affected by irradiation only in the $7^{\text {th }} \mathrm{dph}$, it was approximately $35 \%$ lower in irradiated fruits in this day. This difference may be ascribed to a delay in ripening, which is associated with the higher firmness of irradiated fruit. This result is in agreement with Heinonen et al. [16] and Thomas and Beyers [2] showed the biosynthesis and accumulation of carotenoids is responsible for development of yellow-orange color of the papaya fruit skin and that this event is correlated to maturation.

In addition it has been demonstrated that there is an increase in the carotenoids content during ripening of fruits as mangoes, oranges, papayas and carambola [16-19]. This increase could also be observed in this study (Figure 1).

Conflicting data regarding to the effect of radiation on the total carotenoids content have been described in the literature. Our results are consistent with reports of Khan et al. [20] and Kilcast [21] that showed losses around $30 \%$ in the carotenoids content of irradiated mangoes and papayas. Boylston et al. [22] described a delay in increasing the carotenoids content during ripening of irradiated oranges and papayas with a dose of $0.75 \mathrm{kGy}$. On the other hand, other studies do not describe changes in the carotenoids content of irradiated mangoes, strawberries, carrots and papayas $[23,24]$.

In addition, the irradiation did not affect lycopene content. Although this carotenoid has not provitamin an activity, it has recently emerged as an efficient antioxidant. Considering that papaya is one of the few sources of lycopene, this result suggests that irradiation does not affect this functional property given by this compound.

\section{Vitamin C}

Like as carotenoids the vitamin $\mathrm{C}$ display an important roles in metabolism and in scavenging Reactive Oxygen Species (ROS) in biological systems. Furthermore, vitamin $\mathrm{C}$ is involved in several metabolic processes and in control of growth, cell division and expansion of the cell wall of vegetables.

Our results demonstrated that vitamin $\mathrm{C}$ content was significantly lower in irradiated fruits in the evaluated days. Like the carotenoids it has also been pointed out a positive correlation between vitamin 
Citation: de Figueiredo SG, Silva-Sena GG, de Santana EN, dos Santos RG, Neto JO, et al. (2014) Effect of Gamma Irradiation on Carotenoids and Vitamin C Contents of Papaya Fruit (Carica papaya L.) Cv. Golden. J Food Process Technol 5: 337. doi:10.4172/2157-7110.1000337

Page 4 of 5

\begin{tabular}{|c|c|c|c|c|}
\hline Papaya fruits & Portion (g) & Vitamin A Value ( $\mu$ g RE) & $\%$ of the Adequacy for children & $\%$ of the Adequacy for adults \\
\hline Control $\left(7^{\text {th }} \mathrm{dph}\right)$ & 200 & $255.7 \pm 30.37$ & $56.31-71.49$ & $28.11-35.69$ \\
\hline Irradiated ( $\left(9^{\text {th }} \mathrm{dph}\right)$ & 200 & $339.4 \pm 11.85$ & $81.84-87.76$ & $40.92-43.88$ \\
\hline
\end{tabular}

** It is used to calculation of the adequacy of the vitamin A value, the recommendation of a daily intake of $800 \mu \mathrm{g}$ de $\mathrm{RE}$ (adults) and $400 \mu \mathrm{RE}$ (children) according to the DRI's - Dietary Reference Intakes [15].

Table 1: Adequacy of the vitamin A value $(\%)$ in relation to consumption of the portion $(200 \mathrm{~g})$ of the controls and irradiated fruits **

\begin{tabular}{|c|c|c|c|c|}
\hline Papaya fruits & Portion (g) & Vitamin C (mg) & $\%$ of the Adequacy for children & $\%$ of the Adequacy for adults \\
\hline Control ( $\left.7^{\text {th }} \mathrm{dph}\right)$ & 200 & $216.48 \pm 12.0$ & $817.9-913.9$ & $255.6-285.6$ \\
\hline Irradiated $\left(9^{\text {th }} \mathrm{dph}\right)$ & 200 & $132.24 \pm 9.34$ & $491.6-566.3$ & $153.6-176.9$ \\
\hline
\end{tabular}

** It is used to calculation of the adequacy of the vitamin C, the recommendation of a daily intake of $80 \mathrm{mg}$ (adults) and $25 \mathrm{mg}$ (children) of the vitamin $\mathrm{C}$ according to the DRI's - Dietary Reference Intakes [15].

Table 2: Adequacy of the vitamin C (\%) in relation to consumption of the portion $(200 \mathrm{~g})$ of the controls and irradiated fruits **.

C content and fruits process maturation. Fry [25] and Smirnoff [26] demonstrated that the presence of ascorbic acid results in decrease of the medium $\mathrm{pH}$, which actives expansins, (cell wall proteins that induce cell wall extension and are thought to mediate $\mathrm{pH}$-dependent cell expansion, thus preventing the accession of polysaccharides), which facilitates fruit maturation. It is believed that the lower level of this vitamin reduces the activity of these proteins, which causes a delay in ripening of the fruit.

In addition, Jiménez et al. [27] evaluated the vitamin C content during the ripening of the tomato fruits and observed that the increase in the concentration of ascorbic acid was accompanied by pulp softening and Gray et al. [28] reported that the vitamin C is involved in the synthesis of ethylene hormone.

The lowest values of vitamin $\mathrm{C}$ found in this work for the irradiated papaya were also described for irradiated tangerines, tomatoes, papayas and mangoes [2,29,30]. However, Basson et al. [31], Beyers et al. [24], Boylston et al. [22], and Patil et al. [32] showed that doses up to 1.0 $\mathrm{kGy}$ of irradiation did not influence the vitamin $\mathrm{C}$ content of mangoes, grapefruit, strawberries and tomatoes.

Sajilata and Singhal [33] describe still that a decrease in antioxidant content of foods can be correlated with the neutralization of ROS, which are produced by irradiation. Moreover, it was likely that higher levels of these antioxidants indicated the performance of other antioxidant compounds.

\section{Adequacy of vitamin $A$ and vitamin $C$ values in relation to daily consumption}

Human are unable to synthesize carotenoids, because they are precursors of vitamin $\mathrm{A}$ are essential to the diet. $\beta$-carotene and $\beta$-cryptoxanthin are provitamin A carotenoids in the papaya.

Taking into dph with highest concentration these vitamins and/or suitability for consumption and account that $1 / 2$ unit $(\approx 200 \mathrm{~g})$ is the daily intake portion of papaya, adequacy of vitamin $A$ and vitamin $C$ value in the $9^{\text {th }} \mathrm{dph}$ of the irradiated fruits was compared with the $7^{\text {th }}$ for control fruits. Irradiated fruits showed vitamin A adequacy of 81.84$87.76 \%$ for children, and $40.92-43.88 \%$ for adults and control fruits, 56.31-71.49\% (children) and 28.11-35.69\% (adults) (Table 1). Despite irradiated fruits presented lower vitamin $\mathrm{C}$ content, this fruits presents adequacy the requirements demanded of this vitamin (Table 2).

\section{Conclusion}

In conclusion our data demonstrate that the use of irradiation $(0.8$ $\mathrm{kGy}$ ) as a conservation process, regardless of induced alterations in the papaya fruits total carotenoids and vitamin C levels, does not affect its nutritional potential, no adequacy of daily nutritional requirements of these nutrients.

\section{Acknowledgment}

This work was supported by FAPES (process 0068/2007), Banco Do Nordeste ETENI-FUNDECI (process 2005-1039). The authors are indebted to: Caliman Agricola S/A for providing fruits and the Ricardo Ferracini, by fruits irradiation.

\section{References}

1. Akamine EK, Moy JH (1983) Delay in postharvest ripening and senescence of fruits. Preservation of Food by lonizing Radiations, CRC Press, West Palm Beach, FL.

2. Thomas AC, Beyers M (1979) y Irradiation of Subtropical Fruits. A comparison of the chemical changes occurring during normal ripening of mangoes and papayas with changes produced by $\mathrm{y}$ Irradiation. J Agric Food Chem 27: 157163.

3. D'innocenzo M, Lajolo, FM (2001) Effect of gamma irradiation on softening changes and enzyme activities during ripening of papaya fruit. J Food Biochem 25: $425-438$.

4. Cia P, Pascholati SF, Benato EA, Camili EC, Santos CA (2007) Effects of gamma and UV-C irradiation on the postharvest control of papaya anthracnose. Postharvest Biol and Technol 43: 366-373.

5. Ninjoor $V$ (1989) Use of ionizing radiation for food processing application Indian Society for Radiation Physics 25: 35-41.

6. Cortés C, Torregrosa F, Esteve MJ, Frígola A (2006) Carotenoid profile modification during refrigerated storage in untreated and pasteurized orange juice and orange juice treated with high-intensity pulsed electric fields. J Agric Food Chem 54: 6247-6254.

7. World Health Organization (1998) Studies Rebut Concept That Body Stores Vitamin A Making Substance; WHO: Geneva, Switzerland.

8. Kaur C, Kapoor HC (2001) Antioxidant in fruits and vegetables - the milleium's health. Int J. Food Sci Technol 36: 703-725.

9. Sant'ana HMP, Stringheta PC, Brandão SCC, Azeredo RMC (1998) Carotenoid retention and vitamin A value in carrot (Daucus carota L.) prepared by food service. Food Chem 61: 145-151.

10. Marin SLD, Gomes JA, Salgado JS (1995) Recomendações para a cultura do mamoeiro dos grupos Solo e Formosa no Estado do espírito Santo. Vitória ES. Empresa Capixaba de Pesquisa Agropecuária (EMCAPA, circular técnica 3).

11. Rodriguez-Amaya DB (2001) A guide to carotenoid analysis in foods. Washington DC: International Life Science Institute Press.

12. Rosa JS, Godoy RLO, Neto JO, Campos RS, Matta VM, et al. (2007) Desenvolvimento de um método de análise de vitamina $\mathrm{C}$ em alimentos por cromatografia líquida de alta eficiência e exclusão iônica. Ciênc Tecnol Aliment out/ dez 27: 787-792.

13. Bauernfeind JC (1972) Carotenoid vitamin A precursors and analogs in foods and feeds. J Agric Food Chem 20: 456-473.

14. NAS-NCR (1980) National Academy Of Science/ National Council Research Recommended dietary allowance. 
Citation: de Figueiredo SG, Silva-Sena GG, de Santana EN, dos Santos RG, Neto JO, et al. (2014) Effect of Gamma Irradiation on Carotenoids and Vitamin C Contents of Papaya Fruit (Carica papaya L.) Cv. Golden. J Food Process Technol 5: 337. doi:10.4172/2157-7110.1000337

15. Sheffer M, Taylor CL, Rapporteurs (2008) The Development of DRIs 1994 2004: Lessons Learned and New Challenges: Workshop Summary. Institute of Medicine. The National Academy Press, Washington, DC.

16. Heinonen MI, Ollialinen V, Linkola EK, Varo PT, Koivistoinen PE (1989) Carotenoids in finis foods: vegetables, fruits and berries. J Agric Food Chem 37: $655-659$

17. Gross J, Ikan R, Eckhardt G (1983) Carotenoids of the fruit of Averrhoa carambola. Phytochemistry 22: 1479-1481.

18. John J, Subbarayan C, Cama HR (1970) Carotenoids in 3 stages of ripening of mango. J Food Sci 35: 262-265.

19. Rotstein A, Gross J, Lifshitz A (1972) Changes in the pulp carotenoid pigments of the ripening Shamouti orange. Lebenson-Wiss Technol 5: 140-143.

20. Khan I, Sattar A, Ali M, Muhammed A (1974) Some physiological and biochemical changes in irradiated mangoes. Lebenson-Wiss Technol 7:25-28.

21. Kilcast D (1994) Effect of irradiation on vitamins. Food Chem 49: 157-164.

22. Boylston TD, Reitmeier CA, Moy JH, Mosher GA, Taladriz L (2002) Sensory quality and nutrient composition of three Hawaiian fruits treated by $\mathrm{x}$-irradiation. J Food Qual 25: 419-433.

23. Lima KSC, Lima ALS, Freitas LC, Della-Modesta RC, Godoy RLO (2004) Efeito de baixas doses de irradiação nos carotenóides majoritários em cenouras prontas para o consumo. Ciênc Tecnol Aliment., abr 24: 183-193.

24. Beyers M, Thomas AC, Van Tonder AJ (1979) y Irradiation of Subtropical Fruits. Compositional Tables of Mango, Papaya, Strawberry, and Litchi Fruits at the Edible-Ripe Stage. J Agric Food Chem 27: 37-42.
25. Fry SC (1998) Oxidative scission of plant cell wall polysaccharides by ascorbato-induced hydroxyl radicals. Biochem J 332: 507- 515.

26. Smirnoff N (1996) The function and metabolism of ascorbic acid in plants. Ann Bot 78: 661-669.

27. Jiménez A, Creissen G, Kular B, Firmin J, Robinson S, et al. (2002) Changes in oxidative processes and components of the antioxidant system during tomato fruit ripening. Planta 214: 751-758.

28. Gray JE, Picton S, Giovannoni JJ, Griesrson D (1994) The use of transgenic and naturally occurring mutants to understand and manipulate tomato fruit ripening. Plant Cell Environment 17: 557-571.

29. Castricini A, Medeiros SF, Coneglian RCC, Vital HC (2002) Uso da radiação gama na conservação pós-colheita do tomate de mesa (Lycopersicum esculentum M.): fruto "de vez". Rev. Univ. Rural, Ser. Ciên da Vida 22: 223-229.

30. Jobin M, Lacroix M, Abdellaoui S, Bergeron G, Boubekri C, et al. ( 1992) Effect of gamma irradiation combined with hot water treatment on physical, chemical and organoleptic properties of tangerines. Microbiol Aliment Nutr 10: 115-128.

31. Basson RA, Beyers M, Thomas AC (1979) A radiation chemical approach to the evaluation of the possible toxicity of irradiated fruits: Part 1-The effect of protection by carbohydrates. Food Chem apr 4: 131-142.

32. Patil BS, Vanamala J, Hallman G (2004) Irradiation and storage influence on bioactive components and quality of early and late season 'Rio Red' grapefruit (Citrus paradise Macf). Postharvest Biol and Technol 34: 53-64.

33. Sajilata MG, Singhal RS (2006) Effect of irradiation and storage on the antioxidative activity of cashew nuts. Radiat Phys Chem 75: 297-300. 